\title{
APLIKASI PENGAWET PADA KAYU KARET DAN PEMANFAATANNYA UNTUK " FLOORING"
}

\author{
Yuni Adingisih " \\ ABSTRACT
}

\begin{abstract}
Preserving rubber wood (Hevea brasiliensis) can avoid quality decrease that caused by termite and fungi. For preserving rubber wood we can use "Blue Vitriol (Terusi)" with sulphur copper as active material. This research used $3 \%$ and $5 \%$ concentration of Blue Vitriol, while for preserving we use a simple and pressure method. The simple method contained dyeing, varnish, and submersion of rubber wood in preserving. It pressure method used empty cell and complete cell method, with 3 time variable of pressure, they were $0.5,1$, and 2 hours.

The result of this research, concluded that the most effective simple method of preserving to avoid the attack of fungi and termite was submersion for 1 hour and $5 \%$ concentrate of preservative material. While when using pressure method the effective way was using 0.5 hour and $3 \%$ concentrate of preservative material.
\end{abstract}

Keywords : blue vitriol, preservative methode, blue stain

\section{PENDAHULUAN}

$\mathrm{H}$ utan Indonesia dikenal sebagai hutan yang mengalami deforestrasi yang tinggi di dunia. Diperkirakan deforestrasi hutan Indonesia sebesar 1.6 sampai 1.8 juta hectars pertahun, sedangkan WALHI (Wahana Lingkungan Hidup Indonesia) mengungkapkan data terjadinya deforestrasi di Indonesia rata-rata 2.0 juta per tahun. Tingginya deforestrasi di Indonesia disebabkan oleh tiga penyebab utama, illegal logging, perambahan hutan dan kebakaran hutan. Sampai Januari 2001 telah tercatat 360 HPH (Hak Penguasaan Hutan) yang mencakup area 38.9 juta hektar hutan konversi dan produksi. Jumlah tersebut berarti mengalami penurunan sekitar 35 persen dibanding tahun 1990. (anonim, 2007).

Penurunan potensi kayu dari hutan alam yang telah dan sedang terjadi saat ini berdampak besar terhadap perkembangan dan keberadaan industri perkayuan nasional termasuk industri flooring di Kalimantan Timur. Industri-industri ini kemudian memanfaatkan kayu karet (Hevea brasiliensis) dari tanaman karet yang tidak produktif menghasilkan getah lagi sebagai bahan baku alternatifnya. Secara umum, sifat fisik dan mekanik jenis kayu (kelas kuat II) ini memenuhi syarat untuk dijadikan produk flooring, hanya saja kenampakan permukaan kayunya (warna dan tekstur) mudah berubah setelah proses pengolahan. Perubahan ini sangat mungkin diakibatkan oleh adanya sisa-sisa getah (ekstraktif) di dalam kayu yang kemudian keluar setelah kayu dipotong, dikatam atau diamplas. (Dumanauw,2001).

\section{BAHAN DAN METODE}

Bahan yang digunakan dalam penelitian ini adalah kayu karet yang sudah tidak produktif dan dipotong sesuai ukuran Flooring ( SNI 01-5008.13-2002) yaitu $20 \mathrm{~mm} \times 60 \mathrm{~mm} \times 400 \mathrm{~mm}$. Bahan kimia sebagai bahan pengawet berupa Tembaga Sulfat (Cupri Sulfat).

Sebelum dilakukan pengawetan kayu karet dikondisikan di ruang konstan dengan suhu $25 \pm 2^{\circ} \mathrm{C}$ dan kelembaban kurang dari $65 \%$ dengan maksud agar kadar air di kayu dapat berkurang 
can stabil.

Metode pengawetan yang dilakukan sebagai berikut:

Proses sederhana (tanpa tekanan) yaitu dengan cara:

- dilabur dengan berat labur $3 \mathrm{~g} / \mathrm{sampel}$

- dicelup

- direndam selama 1 jam.

2. Proses dengan tekanan dilakukan dengan 2 (dua) metode yaitu

- Proses sel penuh

Proses ini dilakukan dengan cara memasukkan Blue Vitriol sebanyak mungkin ke dalam kayu dengan proses penekanan. Pengawetan ini menggunakan vakum awal $60 \mathrm{cmHg}$ selama 15 menit, kemudian diberi tekanan sebesar $10 \mathrm{~atm}$ dengan variable waktu 0.5 jam, 1 jam dan 2 Setelah itu dilakukan vakum akhir $60 \mathrm{cmHg}$ selama 15 menit.

- Proses selkosong.

Pengawetan ini dilakukan dengan melapisi sel-sel penyusun kayu dengan menggunakan tekanan, tetapi bagian rongga kayu /sel kayu masih kosong. Pengawetan dilakukan langsung memberi tekanan sebesar $10 \mathrm{~atm}$ selama $0.5,1$ dan 2 jam kemudian vakum akhir $60 \mathrm{cmHg}$ selama 15 menit.

Jenis pengamatan yang dilakukan terhadap proses pengawetan adalah uji retensi, ketahanan terhadap rayap dan ketahanan terhadap jamur.

\section{HASIL DAN PEMBAHASAN}

Retensi

Dari hasil penelitian diperoleh data sebagai berikut :

Retensi adalah suatu ukuran yang menggambarkan banyaknya atau beratnya Blue Vitriol yang dapat dikandung oleh kayu setelah diawetkan. Semakin banyak jumlah pengawet yang menetap (terfiksasi) dalam kayu, retensi bahan pengawet juga semakin besar. Dari hasil penelitian diperoleh data retensi untuk metode sederhana yaitu celup, rendam dan labur dengan honsentrasi Blue Vitriol $3 \%$ pada Gambar 1:

\section{Retensi Metode Sederhana Konsentrasi $3 \%$}

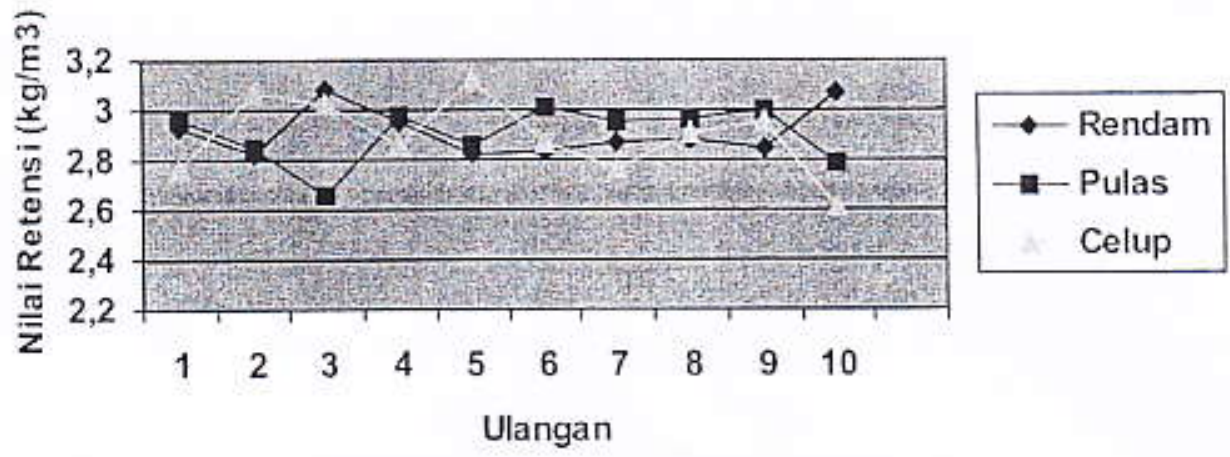

Gambar 1. Nilai Retensi Metode Sederhana Konsentrasi 3\%

Dari gambar 1 dapat dilihat nilai rata-rata retensi untuk metode rendam sebesar 2,913293 $\mathrm{kg} / \mathrm{m}^{3}$, sedangkan dengan metode pelaburan diperoleh nilai rata-rata retensi sebesar 2,901088 $\mathrm{kg} / \mathrm{m}^{3}$. Metode pencelupan diperoleh nilai rata-rata retensi sebesar $2,892655 \mathrm{~kg} / \mathrm{m}^{3}$. Dari ketiga metode sederhana tersebut menunjukkan bahwa nilai rata-rata retensi sebesar $2,9 \mathrm{~kg} / \mathrm{m}^{3}$, di mana nilai tersebut di bawah standar yang diharapkan untuk nilai retensi menggunakan tembaga Sulfat yaitu sebesar $4-20 \mathrm{~kg} / \mathrm{m}^{3}$ (Willeitner dan Liese, 2006).

Nilai Retensi menggunakan metode sederhana dengan konsentrasi $5 \%$, diperoleh pada gambar 2 . 


\section{Retensi Metode Sederhana Konsentrasi $5 \%$}

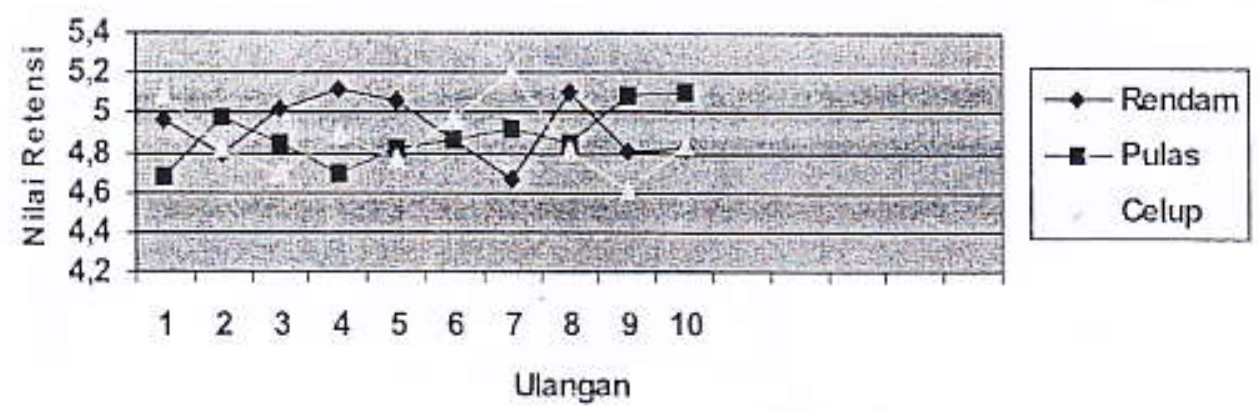

Gambar 2. Nitai Retensi Metode Sederhana Kc.nsentrasi 5\%

Nilai rata-rata retensi untuk metode rendam dengan konsentrasi Blue Vitriol $5 \%$ sebesar 4.921539 $\mathrm{kg} / \mathrm{m}^{3}$. Untuk metode labur diperoleh nilai rata-rata retensi sebesar $4,882966 \mathrm{~kg} / \mathrm{m}^{3}$. Sedangkan dengan pencelupan diperoleh nilai rata-rata retensi sebesar $4,869662 \mathrm{~kg} / \mathrm{m}^{3}$. Gambar 2 menunjukkan bahwa untuk metode sederhana dengan konsentrasi Blue Vitriol $5 \%$ mempunyai nilai rata-rata retensi sebesar $4,9 \mathrm{~kg} / \mathrm{m}^{3}$, di mana nilai tersebut masuk dalam standar yang diharapkan, yaitu $4-20 \mathrm{~kg} / \mathrm{m}^{3}$ (Willeitner dan Liese, 2006).

Untuk proses bertekanan, dilakukan dengan dua metode yaitu sel kosong dan sel penuh. Pada metode sel penuh, kayu karet divakum sebelum diberi tekanan. Tujuan divakum adalah untuk mengeluarkan udara yang ada di dalam sel-sel kayu sehingga pada saat diberi pengawet dengan cara ditekan, pemasukan bahan pengawet dapat maksimal dan mengisi penuh rongga-rongga pada kayu. Proses penekanan dilakukan dengan variabel waktu selama 0,5 jam, 1 jam dan 2 jam sebagaimana pada Gambar 3.

\section{NILAI RETENSI SEL PENUH KONSENTRASI PENGAWET $3 \%$}

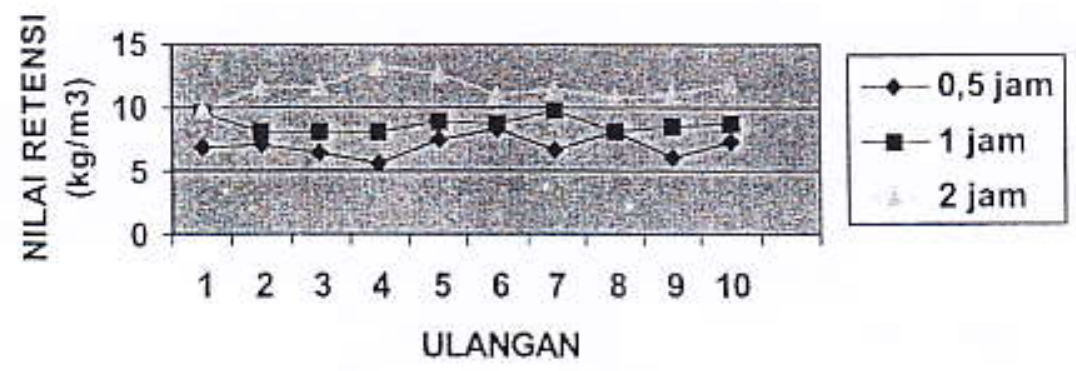

Gambar 3. Nilai Retensi Metode Sel Penuh Konsentrasi 3\%

Dari gambar 3 dapat dilihat bahwa waktu tekan mempengaruhi nilai retensi. Semakin lama waktu tekan semakin tinggi pula retensinya. Nilai retensi metode sel penuh dengan konsentrasi Blue Vitriol $3 \%$ menghasilkan nilai retensi $7,0 \mathrm{~kg} / \mathrm{m}^{3}$ dengan waktu tekan $0,5 \mathrm{jam}$. Sedang untuk waktu tekan 1 jam dan 2 jam masing-masing nilai retensinya adalah $8,68 \mathrm{~kg} / \mathrm{m}^{3}$ dan $11,52 \mathrm{~kg} / \mathrm{m}^{2}$ sesuai dengan standar yang diharapkan yaitu $4-20 \mathrm{~kg} / \mathrm{m}^{3}$ (Willeitner dan Liese, 2006).

Untuk pengawetan dengan metode sel penuh dengan konsentrasi Blue Vitriol $5 \%$ diperoleh pada Gambar 4. 


\section{Nilai retensi Sel Penuh Konsentrasi 5\%}

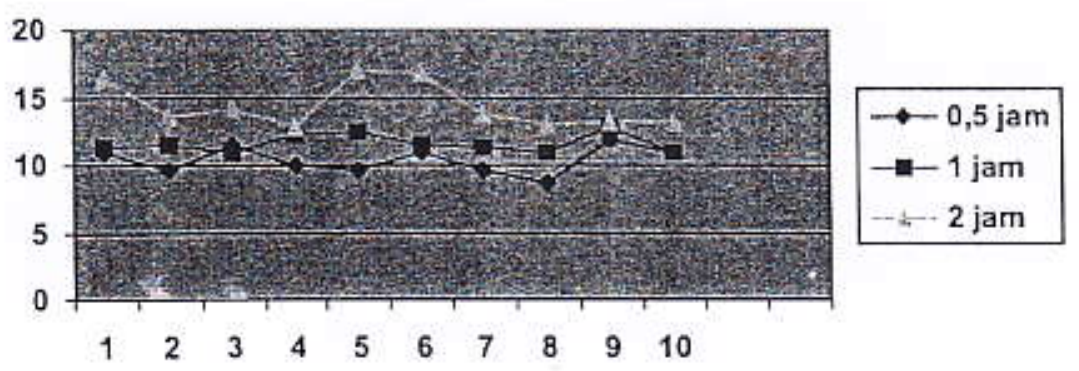

Gambar 4. Nilai Retensi Metode Sel Penuh Konsentrasi Pengawet 5\%

Dari gambar 4 nilai retensi dengan konsentrasi $5 \%$ dengan waktu tekan 0.5 jam diperoleh nilai rata-rata sebesar $10,383767 \mathrm{~kg} / \mathrm{m}^{3}$, waktu tekan 1 jam diperoleh rata-rata $11,609659 \mathrm{~kg} / \mathrm{m}^{3}$, sedangkan waktu tekan 2 jam diperoleh rata-rata $14,389495 \mathrm{~kg} / \mathrm{m}^{3}$. Dari nilai tersebut semakin lama waktu tekan semakin tinggi pula nilai retensi yang diperoleh. Nilai retensi sangat tinggi sehingga kayu tahan terhadap serangan jamur dan rayap. Tetapi dari segi ekonomi penggunaan konsentrasi $5 \%$ lebih mahal dari pada $3 \%$.

Untuk nilai retensi dengan metode sel kosong dengan berbagai variabel konsentrasi dan waktu dapat dilihat pada Gambar 5.

\section{Nilai Retensi Sel Kosong Konsentrasi 3\%}

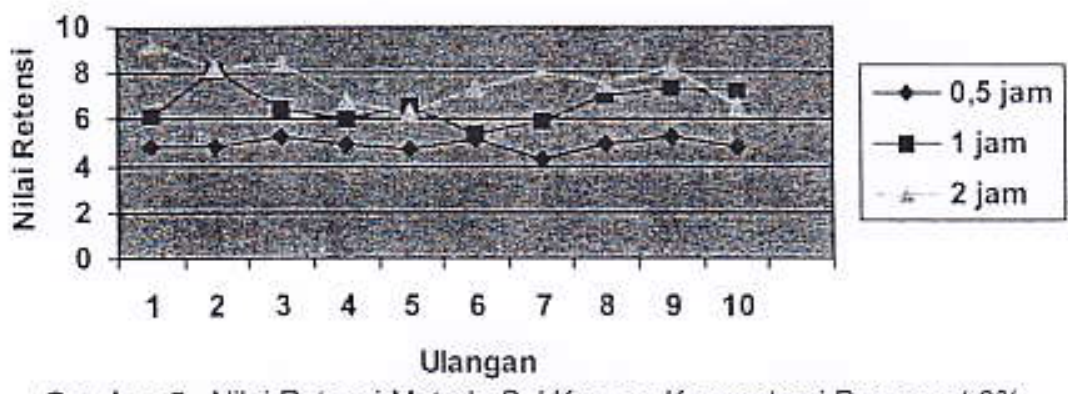

Gambar 5. Nilai Retensi Metode Sel Kosong Konsentrasi Pengawet 3\%

Dari gambar 5 dapat dilihat bahwa nilai rata-rata retensi dengan metode kosong untuk konsentrasi $3 \%$ dengan waktu tekan 0,5 jam diperoleh nilai rata-rata $4,907993 \mathrm{~kg} / \mathrm{m}^{3}$, untuk waktu tekan 1 jam diperoleh nilai rata-rata $6,646513 \mathrm{~kg} / \mathrm{m}^{3}$, waktu tekan 2 jam diperoleh nilai rata-rata $7,687568 \mathrm{~kg} / \mathrm{m}^{3}$. Dari gambar di atas dapat dilihat semakin lama waktu tekan semakin tinggi pula nilai retensi yang dihasilkan. Untuk nilai retensi metode sel kosong dengan konsentrasi Blue Vitriol $5 \%$ diperoleh data pada Gambar 6.

\section{Nilai Retensi Sel Konsentrasi $5 \%$}

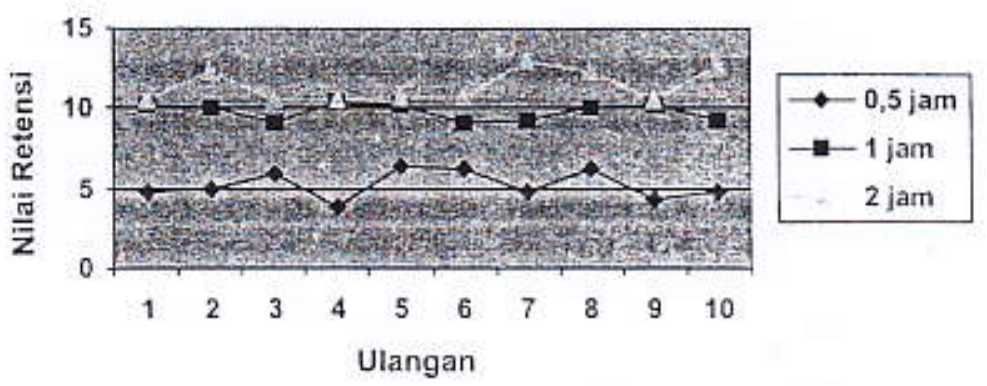

Gambar 6. Nilai Retensi Metode Sel Kosong Konsentrasi pengawet $5 \%$ 
Dari gambar 6 dapat dilihat nilai retensi untuk konsentrasi pengawet $5 \%$ dengan waktu tekan 0,5 (setengah) jam diperoleh nilai rata-rata $5,193996 \mathrm{~kg} / \mathrm{m}^{3}$, waktu tekan 1 jam nilai rata-rata retensinya sebesar $9,755712 \mathrm{~kg} / \mathrm{m}^{3}$ dan waktu tekan 2 jam diperoleh nilai rata-rata 11,383206 $\mathrm{kg} / \mathrm{m}^{3}$. Dari gambar 6 dapat dilihat bahwa nilai retensi berbanding lurus dengan waktu tekan baik secara sel kosong maupun sel penuh.

\section{Ketahanan Terhadap Rayap}

Kayu yang telah dilakukan proses pengawetan diuji ketahanannya terhadap rayap. Data yang diperoleh berdasarkan susut berat atau kehilangan berat kayu setelah diserang rayap.

1. Metode Sederhana

Dari metode sederhana baik perlakuan pelaburan, pencelupan maupun perendaman dengan konsentrasi pengawet $3 \%$ dan $5 \%$ diperoleh nilai rata-rata pada tabel 1 .

Tabel 1. Susut kayu pada pengujian Ketahanan Rayap metode Sederhana

\begin{tabular}{|c|c|c|}
\hline \multirow{2}{*}{ Perlakuan } & \multicolumn{2}{|c|}{ Nilai Rata - rata } \\
\cline { 2 - 3 } & $3 \%$ & $5 \%$ \\
\hline Pelaburan & 10,19 & 11,86 \\
\hline Pencelupan & 7,40 & 9,06 \\
\hline Perendaman & 5,50 & 3,68 \\
\hline
\end{tabular}

Dari tabel 1 perlakuan yang menghasilkan nilai susut berat paling sedikit adalah perendaman, baik untuk konsentrasi pengawet 3\% dan 5\%. Menurut SNI 01-7207-2006, klasifikasi ketahanan kayu kelas II (tahan) mempunyai penurunan berat 2,0 4,4\%, sehingga untuk metode perendaman dengan konsentrasi pengawet $5 \%$ dihasilkan kayu dengan klasifikasi tahan rayap.

2. Metode Bertekanan

Pada metode bertekanan dengan metode sel penuh dengan konsentrasi $3 \%$ dan $5 \%$ diperoleh hasil uji terhadap ketahanan rayap pada Tabel 2.

Tabel 2, Susut kayu pada pengujian Ketahanan Rayap metode Tekanan Sel Penuh

\begin{tabular}{|c|c|c|}
\hline \multirow{2}{*}{ Waktu ( jam ) } & \multicolumn{2}{|c|}{ Nilai Rata - rata } \\
\hline 0,5 & $3 \%$ & $5 \%$ \\
\hline 1 & 3,45 & 4,25 \\
\hline 2 & 3,13 & 3,77 \\
\hline
\end{tabular}

Dari tabel 2 di atas dapat dilihat bahwa semakin lama waktu tekan semakin rendah pula susut berat kayu sehingga kayu lebih kuat terhadap serangan rayap. Untuk metode sel penuh menghasilkan ketahanan rayap dengan klasifikasi kelas II (tahan). (SNI-01-7207-2006 Uji Ketahanan Kayu dan Produk Kayu Terhadap Organisme Perusak Kayu).

Untuk metode sel kosong baik konsentrasi $3 \%$ dan $5 \%$ dapat dilihat pada Tabel 3 .

Tabel 3. Susut kayu pada pengujian Ketahanan Rayap metode Tekanan Sel Kosong

\begin{tabular}{|c|c|c|}
\hline \multirow{2}{*}{ Waktu ( jam ) } & \multicolumn{2}{|c|}{ Nilai Rata - rata } \\
\cline { 2 - 3 } & $3 \%$ & $5 \%$ \\
\hline 0,5 & 4,48 & 5,38 \\
\hline 1 & 3,74 & 4,17 \\
\hline 2 & 2,97 & 2,89 \\
\hline
\end{tabular}

Sama halnya dengan metode sel penuh, nilai rata-rata ketahanan uji terhadap rayap semakin kecil dengan semakin lamanya waktu tekan (semakin banyak bahan pengawet yang masuk dalam kayu). Perlakuan pengawetan menggunakan sel penuh lebih baik dari pada sel kosong, karena dengan waktu tekan 0,5 jam untuk metode sel kosong menghasilkan kayu dengan 
klasifikasi kelas III (sedang) dengan batas susut 4,4 8,2\% (SNI 01-7207-2006).

Dari semua perlakuan pengawetan, untuk hasil uji terhadap ketahanan rayap menunjukkan bahwa bahan pengawet Blue Vitriol mampu meminimalkan serangan rayap. Karena di banding dengan kayu yang tidak diberi perlakuan pengawetan (kontrol) penurunan beratnya sampai $24 \%$.

\section{Ketahanan Terhadap Serangan Jamur}

Hasil uji yang dilakukan untuk serangan jamur dilakukan secara visual, dimana kayu yang diberi Blue Vitriol maupun tidak disimpan dalam kondisi tertentu. Adapun hasil uji terhadap rayap dapat dilihat pada Tabel 4 dan 5 .

Tabel 4. Ketahanan Terhadap Jamur Metode sederhana

\begin{tabular}{|l|r|c|c|c|c|c|}
\hline \multirow{2}{*}{ Kondisi Penyimpanan } & \multicolumn{3}{|c|}{ Konsentrasi Pengawet 3\% } & \multicolumn{3}{c|}{ Konsentrasi Pengawet $5 \%$} \\
\cline { 2 - 7 } & Labur & Rendam & Celup & Labur & Rendam & Celup \\
\hline Suhu $30-35^{\circ} \mathrm{C}, \mathrm{RH} 60 \%$ & 2 hari & 3 hari & 2 hari & 4 hari & 5 hari & 4 hari \\
\hline Suhu $25^{\circ} \mathrm{C}, \mathrm{RH} 70 \%$ & 21 hari & 28 hari & 21 hari & 21 hari & 28 hari & 21 hari \\
\hline
\end{tabular}

Tabel 5. Ketahanan Terhadap Jamur Metode bertekanan

\begin{tabular}{|l|c|c|c|c|}
\hline \multirow{2}{*}{ Kondisi Penyimpanan } & \multicolumn{2}{|c|}{ Konsentrasi $3 \%$} & \multicolumn{2}{c|}{ Konsentrasi $5 \%$} \\
\cline { 2 - 5 } & Sel penuh & Sel kosong & Sel penuh & Sel kosong \\
\hline Suhu $30-35^{\circ} \mathrm{C}, \mathrm{RH} 60 \%$ & 6 hari & 3 hari & 7 hari & 4 hari \\
\hline Suhu $25^{\circ} \mathrm{C}, \mathrm{RH} 70 \%$ & 35 hari & 28 hari & 35 hari & 28 hari \\
\hline
\end{tabular}

Dari tabel 4 dan 5 dapat dilihat bahwa untuk metode sederhana dengan konsentrasi $3 \%$ dan $5 \%$ mempunyai keawetan terhadap jamur sampai 4 minggu. Sedang untuk metode bertekanan dengan sel penuh diperoleh daya tahan terhadap jamur lebih tinggi dari pada sel kosong.

\section{Pengujian Papan lantai (Flooring)}

Dari hasil perlakuan pengawetan dengan hasil uji yang memenuhi syarat dan lebih ekonomis diperoleh perlakuan pengawetan sederhana yaitu metode perendaman dengan konsentrasi Blue Vitriol 5\%. Untuk metode bertekanan dilakukan metode sel penuh dengan konsentrasi Blue Vitriol 3\% selama 0,5 jam. Hasil dari perlakuan tersebut kemudian diuji sesuai SNI 01-5008.13-2002 Papan Lantai Kayu rimba dapat dilihat pada Tabel 6 dan 7:

Tabel 6. Mutu Papan Lantai dengan pengawetan metode se Jerhana

\begin{tabular}{|l|c|c|c|c|c|}
\hline \multicolumn{1}{|c|}{ Cacat } & Sampel 1 & Sampel 2 & Sampel 3 & Sampel 4 & $\begin{array}{c}\text { SNI } \\
\text { Mutu B }\end{array}$ \\
\hline Cacat teknis & & & & & \\
\hline Celah & rapat & rapat & rapat & rapat & rapat \\
\hline Pecah & $\mathrm{x}$ & $\mathrm{x}$ & $\mathrm{x}$ & $\mathrm{v}$ & $\mathrm{x}$ \\
\hline Lengkung & $\mathrm{x}$ & $\mathrm{x}$ & $\mathrm{x}$ & $\mathrm{x}$ & $\mathrm{x}$ \\
\hline Kesikuan & siku & siku & siku & siku & siku \\
\hline Permukaan & halus - rata & halus - rata & halus - rata & halus - rata & halus - rata \\
\hline Keserasian warna & serasi & serasi & serasi & serasi & serasi \\
\hline Perubahan warna & $\mathrm{x}$ & $\mathrm{x}$ & $\mathrm{x}$ & $\mathrm{v}$ & $\mathrm{x}$ \\
\hline $\begin{array}{l}\text { Pemilahan kayu } \\
\text { gergajian }\end{array}$ & baik & baik & baik & baik & baik \\
\hline
\end{tabular}




\begin{tabular}{|l|c|c|c|c|c|}
\hline Bekas tinta/lem & $\mathrm{x}$ & $\mathrm{x}$ & $\mathrm{x}$ & $\mathrm{x}$ & $\mathrm{x}$ \\
\hline Cacat alami & & & & & \\
\hline $\begin{array}{l}\text { Lubang gerek kecil } \\
\text { terbuka/didempul }\end{array}$ & $\mathrm{x}$ & $\mathrm{x}$ & $\mathrm{x}$ & $\mathrm{x}$ & $\mathrm{x}$ \\
\hline Mata kayu busuk & $\mathrm{x}$ & $\mathrm{x}$ & $\mathrm{x}$ & $\mathrm{x}$ & $\mathrm{x}$ \\
\hline Mata kayu sehat & $\varnothing 0,3$ & $\emptyset 0,4$ & $\begin{array}{c}\emptyset 0,3 \\
\varnothing 0,4 \\
\varnothing 0,25\end{array}$ & $\mathrm{x}$ & $\begin{array}{c}<3 \text { buah } \\
\varnothing \leq 1,5\end{array}$ \\
\hline Gubal & $\mathrm{x}$ & $\mathrm{x}$ & $\mathrm{x}$ & $\mathrm{x}$ & $\mathrm{x}$ \\
\hline Jamur biru & $\mathrm{v}$ & $\mathrm{x}$ & $\mathrm{x}$ & $\mathrm{x}$ & $\mathrm{x}$ \\
\hline Bercak hitam & $\mathrm{x}$ & $\mathrm{x}$ & $\mathrm{x}$ & $\mathrm{x}$ & $\mathrm{x}$ \\
\hline $\begin{array}{l}\text { Jamur atau cacat } \\
\text { lain }\end{array}$ & $\mathrm{x}$ & $\mathrm{x}$ & $\mathrm{x}$ & $\mathrm{x}$ & $\mathrm{x}$ \\
\hline
\end{tabular}

Tabel 7. Mutu Papan Lantai dengan pengawetan metode tekanan sel penuh

\begin{tabular}{|c|c|c|c|c|c|}
\hline Cacat & Sampel 1 & Sampel 2 & Sampel 3 & Sampel 4 & $\begin{array}{c}\text { SNI } \\
\text { Mutu B }\end{array}$ \\
\hline \multicolumn{6}{|l|}{ Cacat teknis } \\
\hline Celah & rapat & rapat & rapat & rapat & rapat \\
\hline Pecah & $x$ & $x$ & $x$ & v & $x$ \\
\hline Lengkung & $\mathrm{x}$ & $x$ & $x$ & $x$ & $x$ \\
\hline Kesikuan & siku & siku & siku & siku & siku \\
\hline Permukaan & halus - rata & halus - rata & halus - rata & halus - rata & halus - rata \\
\hline Keserasian warna & serasi & serasi & serasi & serasi & serasi \\
\hline Perubahan warna & $x$ & $x$ & $x$ & v & $x$ \\
\hline $\begin{array}{l}\text { Pemilahan kayu } \\
\text { gergajian }\end{array}$ & baik & baik & baik & baik & baik \\
\hline Bekas tinta/lem & $x$ & $x$ & $x$ & $x$ & $x$ \\
\hline \multicolumn{6}{|l|}{ Cacat alami } \\
\hline $\begin{array}{l}\text { Lubang gerek kecil } \\
\text { terbuka/didempul }\end{array}$ & $\mathrm{x}$ & $\mathrm{x}$ & $x$ & $x$ & $x$ \\
\hline Mata kayu busuk & $x$ & $x$ & $x$ & $\mathrm{x}$ & $x$ \\
\hline Mata kayu sehat & $\varnothing 0,15$ & 00,3 & $x$ & $\begin{array}{ll}\oslash & 0,3 \\
\emptyset & 0,4\end{array}$ & $\begin{array}{l}<3 \text { buah } \\
\varnothing \leq 1,5\end{array}$ \\
\hline Gubal & $x$ & $x$ & $x$ & $x$ & $x$ \\
\hline Jamur biru & $v$ & $x$ & $x$ & $\mathrm{x}$ & $x$ \\
\hline Bercak hitam & $x$ & $x$ & $x$ & $x$ & $x$ \\
\hline $\begin{array}{l}\text { Jamur atau cacat } \\
\text { lain }\end{array}$ & $x$ & $x$ & $x$ & $x$ & $x$ \\
\hline
\end{tabular}

Dari hasil pengujian pada tabel 6 dan 7, mutu kayu karet yang telah diberi perlakuan memenuhi syarat SNI 01-5008.13-2002 papan lantai untuk mutu B, mutu kayu yang dalam penggunaanya mengalami pelapisan (cat, pelitur dan lain-lain). 


\section{KESIMPULAN}

Dari hasil penelitian yang dilakukan dapat disimpulkan :

Nilai retensi yang dihasilkan melalui proses pengawetan dengan cara sederhana yang memenuhi standar untuk bahan pengawet Blue Vitriol adalah metode perendaman selama 1 jam dengan konsentrasi $5 \%$. Nilai retensi yang paling ekonomis dihasilkan melalui proses pengawetan dengan metode bertekanan sel penuh dengan waktu tekan selama 0,5 jam dengan konsentrasi pengawet $3 \%$. Ketahanan terhadap rayap, metode perendaman dengan konsentrasi Blue Vitriol $3 \%$ dan $5 \%$ lebih tahan terhadap rayap. Metode bertekanan dengan konsentrasi $3 \%$ dan $5 \%$ dengan waktu 2 jam menunjukkan nilai susut lebih kecil .Konsentrasi 3\% dan $5 \%$ dengan metode sederhana (rendam) pada suhu $25^{\circ} \mathrm{C}$ dan $\mathrm{RH} 70 \%$ menunjukkan ketahanan terhadap jamur selama 28 hari. Metode bertekanan (sel penuh) ketahanan terhadap jamur menunjukkan waktu 35 hari. Dari hasil uji mutu papan lantai, kayu karet yang telah diberi perlakuan dapat digunakan sebagai papan lantai mutu $B$.

\section{DAFTAR PUSTAKA}

Anonim, 2007, Kondisi hutan Indonesia (http://tumoutou.net70205123/)

Badan Standardisasi Nasional, 2002, SNI 01-5008.13-2002, Papan Lantai Kayu rimba, Jakarta

Badan Standardisasi Nasional, 2003, SNI 01-5010-6-2003. Pencegahan Serangan Jamur Biru pada Kayu Bundar dan Kayu Gergajian, Jakarta

Badan Standardisasi Nasional, 2006, SNI 01-7207-2006, Uji Ketahanan Kayu dan Produk Kayu Terhadap Organisme Perusak Kayu, Jakarta

Dumanauw,2001, J.F, Mengenal Kayu, Kanisius, Yogyakarta

Willeetner dan Liese, 2006, Wood, New York 